\title{
Intellectual Diversity at Religious Colleges
}

\author{
Josiah F. Marineau, Campbellsville University \\ Shawn Williams, Campbellsville University
}

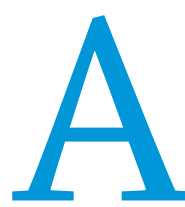

current debate circulating in academia is the extent to which there is a range of intellectual beliefs on campus. If there is, in fact, a lack of a broad range of intellectual views, what are the implications for the way students are taught and the manner in which research is conducted?

Much of the debate has centered on either public research-oriented institutions or Ivy League elite universities. This article describes the intellectual diversity on smaller, religiously affiliated liberal arts colleges (RLACs).

We argue that insofar as intellectual diversity is defined as the breadth of political and ideological affiliations of the faculty, RLACs provide a surprisingly broad range of intellectual diversity compared to many college campuses. This diversity has potential spillover effects on the behavior of political science departments. We back up this argument with survey evidence of the political affiliations of faculty at RLACs. We acknowledge that this diversity may go unnoticed due to a range of sector and institutional factors. First, we suggest that much of the discussion is dominated by a few high-profile RLACs associated with the political right. Second, we contend that the intellectual diversity at RLACs often is masked by the perception that they struggle with other forms of diversity. Some are concerned about the scope of academic freedom at RLACs. RLACs are struggling to accommodate minority students, such as LGBTQ students. We believe that the first concern is overstated, whereas the need to maintain federal aid will lead RLACs to accommodate LGBTQ students. The bigger challenge facing RLACs is financial: the trend of small private colleges closing due to financial constraints is an issue that should concern everyone interested in intellectual diversity on college campuses.

\section{WHAT IS THE PROBLEM?}

An important debate facing academia is whether the preponderance of liberals on US campuses is producing an ideological bias in how colleges perform their traditional missions of conducting research, teaching students, and service. That the preponderance of faculty is liberal on many college campuses is not in doubt. As shown by Abrams (2016), the proportion of faculty at many elite universities leans heavily to the political left, with liberal faculty outnumbering conservative faculty six to one (Jaschik 2016). Some believe that the preponderance of liberal faculty is producing a campus climate that is hostile to ideas not shared by liberals, such as those held by conservative, libertarian, and religious people (Roth 2017). The lack of political diversity among faculty potentially limits the range of ideas to which students are exposed.

If the problem facing many institutions is the lack of ideological and political diversity among their faculties, the question becomes: What to do about it? Some have called for a type of "affirmative action" in faculty hiring to increase the percentage of conservatives, although many (including many conservatives) are reluctant to support it (Jackson 2017). In this context, some are calling attention to the surprising range of intellectual diversity of RLACs in regard to political affiliations (Howard 2017). Kidd (2016) pointed out that he is "struck by the fact that many Christian colleges feature surprising levels of ideological diversity, even as we seek to unify around our common faith." Hillard (2018) believes the following:

Perhaps because people of faith are bound by a deeper ideology, Christian schools have largely managed to avoid the political homogeneity that has stricken so many of our secular universities. In every Christian institution I've visited or where I've had the pleasure to study, interview, or teach, Republicans and Democrats have mixed profitably (if not always easily) in the service of a more important mission than creating another generation of activist drones. Furthermore, since Christ's followers are in the habit of believing that truth both exists and matters-"the truth shall make you free" and all that-Christian colleges are uniquely positioned to resist the relativism that has corrupted the average American campus so thoroughly.

The next section presents evidence that the firsthand experiences of Kidd and Howard are, in fact, generalizable to RLACs as a whole.

\section{EVIDENCE OF INTELLECTUAL DIVERSITY AT RLACS}

RLACs are more intellectually diverse because of the higher representation of conservatives at these colleges compared to other universities. Drawing on survey data from the Higher Education Research Institution, Abrams (2016) showed that non-Catholic, religious universities with lower levels of selectivity in admissions had the highest percentage of conservative faculty (29.7\%) for 2010-2014 (Abrams 2016, table 2). This percentage was notably higher than public universities with lower levels of selectivity in admissions (16.7\%), which had the second largest percentage of conservative faculty. 
Highly selective private colleges were found to have the lowest level of conservative faculty $(6.0 \%)$ and, correspondingly, the highest proportion of liberal faculty $(74 \cdot 1 \%)$.

Although Abrams (2016) presented evidence that nonCatholic religious universities had the highest percentage of conservative faculty, the largest percentage of faculty at these institutions still identified as liberal (40.1\%). In other words, there is evidence of a greater balance between different political viewpoints at these institutions. journalism to criminal justice. Faculty members in political science programs also are frequently asked to step into "representational roles" on campus by leading politically themed events, reporting on local or state news, and interacting with local government officials or members of institutional boards.

On all campuses, the need to provide these social goods impacts the pedagogy and professional behavior of political science faculty. Just as with a media publication, rationally

\section{Although Abrams (2016) presented evidence that non-Catholic religious universities had the highest percentage of conservative faculty, the largest percentage of faculty at these institutions still identified as liberal (40.1\%). In other words, there is evidence of a greater balance between different political viewpoints at these institutions.}

Another study of political affiliations of faculty at religious institutions found a similar pattern. Joeckel and Chesnes (2010) conducted a survey of 1,900 faculty at 95 institutions that are members of the Council of Christian Colleges and Universities, an association of Christian higher-education institutions in the United States and around the globe. They found that $46.1 \%$ of the respondents considered themselves Republican whereas $\mathbf{2 1 . 6 \%}$ identified as Democrat and $\mathbf{2 4 . 8 \%}$ as Independent. Joeckel and Chesnes therefore found a higher percentage of Republicans than Abrams found for conservatives at similar institutions; however, Republicans still did not comprise a majority of the faculty. Joeckel and Chesnes's findings can be compared to a survey conducted by Gross and Simmons (2007) on the political and social views of 1,417 faculty at a wide range of universities: $51 \%$ identified as Democrat, $13.7 \%$ as Republican, and $35.3 \%$ as Independent.

The level of diversity in political affiliations at religious campuses may be surprising. One reason is that a few high-profile cases suggest that religious colleges are predominantly, perhaps even uniformly, conservative. Liberty University, for example, is well known for the endorsement of its president, Jerry Falwell Jr., of then-candidate Donald Trump in 2016. The evidence presented previously suggests that even if some religious campuses are more uniformly conservative, these are outliers and they do not represent the norm.

The range of intellectual diversity on campuses at large may have potential spillover effects on political science programs. It is obvious to state that the same hiring practices that result in greater diversity at large would result in greater diversity in political science specifically. Less obvious is the potential impact that a greater diversity in the campus intellectual marketplace will have on political science programs as "goods providers."

A common challenge to most political science programs, public or private, is that they must serve as "social goods" providers to the broader campus community. Introductory courses are components of foundational/general-education programs. Political science courses are required or elective courses for a diverse set of majors, from teacher education to minded faculty respond to these pressures by altering their programming in ways that provide departmental or professional benefits. As such, faculty members on a more intellectually diverse campus are incentivized to develop degree programs, classroom lectures, and extracurricular activities that appeal to a broader audience.

Additionally, the intellectual diversity of the majors and minors that feed into the political science classroom promotes a more diverse range of classroom discussions than is found on more uniform public college campuses. Finally, the need to address questions of the diversities of faith encourage faculty to expand the concepts that they must address in public discourse. This pressure is amplified as we consider (1) the increased religious sophistication of students, many of whom have received religious training in their foundational programs; and (2) the range of religious diversity in Christian higher education.

\section{WHY ARE RELIGIOUS COLLEGES MORE INTELLECTUALLY DIVERSE?}

RLACs are more intellectually diverse because religious belief, with a few important exceptions, is linked to higher levels of conservatism. For example, Wald and Calhoun (2018, 33) showed that among evangelical Protestants, 58\% identified as conservative, $29 \%$ as moderate, and $14 \%$ as liberal. Similar trends were found for mainline Protestants (i.e., $39 \%$ conservative, $40 \%$ moderate, and $21 \%$ liberal) and Roman Catholics (i.e., $39 \%$ conservative, $28 \%$ moderate, and $33 \%$ liberal). However, people who are not affiliated with a religion tend to lean liberal: $20 \%$ identify as conservative, $39 \%$ as moderates, and $42 \%$ as liberal. The higher proportion of people of faith at RLACs, therefore, is associated with a higher level of conservatives and thus an overall higher level of intellectual diversity than secular institutions.

\section{YET STRUGGLING WITH OTHER FORMS OF DIVERSITY}

Even if RLACs provide more intellectual diversity, it is clear that they struggle with other forms of diversity. One example is the issue of whether the religious commitments of RLACs 
preclude faculty from discussing and researching controversial issues. The basis for this potential conflict is that RLACs have a dual role: not only do they function as secular institutions in that they pursue knowledge, they also have religious commitments. Faculty members at many RLACs are asked to sign a statement of faith as a condition for their employment; failure to adhere to such a statement can result in dismissal. Some have argued that this requirement violates academic freedom, and some even have argued that RLACs with this requirement should be denied accreditation (Conn 2014). announced that operations may be suspended because of an inability to meet expenditures (Jaschik 2018). Private colleges with small endowments are expected to close at a rate of around 11 per year, and those located in the Midwest and Northeast are likely to face a particularly difficult operating environment due to changing demographic patterns (Seltzer 2018).

The survey evidence cited previously on intellectual diversity suggests the important place of these institutions in the landscape of higher education. The loss of these institutions

\section{Even if RLACs provide more intellectual diversity, it is clear that they struggle with other forms of diversity. One example is the issue of whether the religious commitments of RLACs preclude faculty from discussing and researching controversial issues.}

The survey by Joeckel and Chesnes (2010) provided evidence that these concerns about academic freedom are not shared widely by faculty at these universities. Results indicated that $68.7 \%$ of the respondents agreed or strongly agreed that their university is a "place of rigorous intellectual activity"; $53.8 \%$ agreed with the statement that "professors at Christian institutions have more freedom to discuss issues and ask questions than do professors at secular institutions"; and $68.5 \%$ disagreed with the statement that they are "hesitant to discuss certain issues in class" because of their employment at a RLAC (Joeckel and Chesnes 2010, 189).

Another diversity challenge facing RLACs is how to best accommodate their LGBTQ students. Traditional interpretations of scriptural texts at many RLACs make it difficult to accept same-sex relationships among LGBTQ students. For example, Azusa Pacific University recently moved to lift its institutional ban on same-sex relationships; while the board of trustees initially reinstated the ban (Barnhart 2018), it once again was lifted after months of negotiations between student groups and the administration (Jones 2019).

Whether the maintenance of this stance in regard to same-sex relationships is tenable is an open question. The recent Supreme Court decision on same-sex marriage raises the question of whether RLAC policies on same-sex relationships are discriminatory, thereby rendering these institutions ineligible to receive federal aid. Without federal aid, many RLACs would be forced to close; these institutions may need to change their policies to preclude this possibility (Gjelten 2018).

\section{A SITE OF DIVERSITY UNDER SIEGE}

Even if RLACs provide a degree of intellectual diversity not always seen at other types of institutions, the longevity of these campuses is increasingly under threat. Many RLACs are struggling financially because of small endowments, a limited donor base, and increasing operational expenses. RLACs tend to be funded predominantly by student tuition, and competition among universities leads some to discount their tuition packages at unsustainably low rates. Iowa Wesleyan University, for example, discounts its tuition as much as $66 \%$ and recently is something that should concern all who are invested in promoting intellectual diversity.

\section{CONCLUSION}

We argue that insofar as intellectual diversity is defined to mean more equal representation among different political affiliations in the faculty, religious universities provide a greater degree of intellectual diversity. This diversity spills over into how political science professors at these institutions pursue their vocation. However, religious universities struggle with other types of diversity, including sexual and gender expression and forms of academic freedom. In other words, no institutional type is perfect, but each offers unique strengths and challenges. The unique benefits of RLACs should have greater recognition, especially in light of the financial challenges that these institutions are facing.

\section{REFERENCES}

Abrams, Samuel. 2016. The Contented Professors: How Conservative Faculty See Themselves within the Academy. Working Paper. Available at https://papers. ssrn.com/sol3/papers.cfm?abstract_id=2881527.

Barnhart, Melissa. 2018. "Azusa Pacific University Reinstates Ban on LGBT Student Relationships." Christian Post, September 29. Available at www. christianpost.com/news/azusa-pacific-university-reinstates-ban-on-lgbtrelationships-on-campus-227675.

Conn, Peter. 2014. “The Great Accreditation Farce." Chronicle of Higher Education, June 30 . Available at www.chronicle.com/article/The-Great-AccreditationFarce/147425

Gjelten, Tom. 2018. "Christian Colleges Are Tangled in Their Own LGBT Policies." National Public Radio, March 27. Available at www.npr. org/2018/o3/27/591140811/christian-colleges-are-tangled-in-their-ownlgbt-policies.

Gross, Neil, and Solon Simmons. 2007. "The Social and Political Views of American Professors." Working Paper presented at a Harvard University Symposium on Professors and Their Politics.

Hillard, Graham. 2018. "The Case for Christian Colleges." National Review, October 25. Available at www.nationalreview.com/magazine/2018/11/12/ christian-colleges-religious-higher-education.

Howard, Thomas A. 2017. "Christian Colleges in the Age of Trump." Inside Higher Ed, February 14. Available at www.insidehighered.com/ views/2017/02/14/christian-colleges-can-foster-political-diversity-essay.

Jackson, Abby. 2017. "Liberal Colleges Are Recruiting Conservative Professors to 'Stir up Some Trouble." Business Insider, August 10. Available at www. businessinsider.com/affirmative-action-conservative-professors-liberalcolleges-2017-8. 
Profession Symposium: Does Political Science Lack Diversity? Ideologically, That Is

Jaschik, Scott. 2016. "Professors, Politics and New England." Inside Higher Ed, July 5. Available at www.insidehighered.com/news/2016/07/05/ new-analysis-new-england-colleges-responsible-left-leaningprofessoriate.

Jaschik, Scott. 2018. "Another College on the Brink." Inside Higher Ed, November 5. Available at www.insidehighered.com/news/2018/11/05/ iowa-wesleyan-could-become-latest-small-college-close.

Joeckel, Samuel, and Thomas Chesnes. 2010. "A Slippery Slope to Secularization? An Empirical Analysis of the Council for Christian Colleges and Universities." Christian Scholar's Review 39 (2): 177-196.

Jones, Emily. 2019. "Christian University, Azusa Pacific, Lifts Ban on LGBTQ Relationships-Again.” CBN News, March 21. Available at: https://www1. cbn.com/cbnnews/us/2019/march/christian-university-azusa-pacificlifts-ban-on-lgbtq-relationships-again

Kidd, Thomas S. 2016. Letter. First Things, August. Available at www.firstthings. com/article/2016/08/letters.

Roth, Michael S. 2017. "The Opening of the Liberal Mind." Wall Street Journal, May 11. Available at www.wsj.com/articles/the-opening-of-the-liberalmind-1494515186.

Seltzer, Rick. 2018. "Moody's: Private-College Closures at 11 Per Year.” Inside Higher Ed, July 25. Available at www.insidehighered.com/quicktakes/ 2018/07/25/moodys-private-college-closures-11-year.

Wald, Kenneth D. and Allison Calhoun-Brown. 2018. Religion and Politics in the United States. Rowman \& Littlefield. 